\title{
The Research on Investment Countermeasure of National Social Security Fund
}

\author{
Zhiqin Xie \\ Department of economics, University of shijiazhuang vocational college of posts and telecommunications, Hebei Province, China \\ x1141038008@126.com
}

\begin{abstract}
At present, there is a huge gap in our country between the social security fund and pension demand, how to safeguard the social security fund's ability to pay is the urgent problems at present in our country, in order to improve the degree of social security of retirees, countries have issued a series of measures, one of which to allow access to the capital market and entities for the social security fund is an important measures. But according to reports, in 2011 the national social security fund in the capital market investment income is negative. In accordance with the relevant provisions of the social security fund, $40 \%$ investing capital market by the fund companies. So the fund company's income level and the investment philosophy have rather a large influence over the social security fund to maintain or increase its value. In this paper, we mainly research the problems about the commissioned relationship between the national council for social security fund and the fund company and the problems of fund companies in the investment and point out the main reasons for the poor and put forward the corresponding countermeasures.

Index Terms - the national social security fund, fund company capital markets
\end{abstract}

\section{The Present Situation of the National Social Security Fund Investment in the Capital Market.}

The gap between our country social security fund and pension demand has been the most concerned problem to the government and the people. To narrow the gap, government has actively published relevant policy, and adopted a series of measures, including allowing the social security fund to invest in the capital market, the central fiscal budget allocations, transfer of state-owned assets to the social security fund, etc. In accordance with the regulations, the national social security fund can adopt direct investment and indirect investment two ways. The entrusted-investment mainly depends on fund companies to invest the capital market, but the highest ratio should not exceed 40\%. According to a 2011 annual report, fiduciary fund companies on the stock investment accounted for $32.39 \%$, but the yield is only $0.84 \%$. Another, according to the national social security fund earnings situation table, it was the third time that the annual investment yields was low from since in 2000, the first tow are respectively in 2004 and 2008. In 2008, the social security fund earned 23.362 billion yuan in direct investment, but lost 62.734 billion yuan in the sound value of the trading financial asset class and lost 9.372 billion yuan in the equity investment, therefore the rate of return on investment was $-6.79 \%$. That is to say, in $2008,32 \%$ of the social security fund, which was invested in stock lost 39.4 billion. As was showed in table 1
TABLE I Fund income list

Prepared by: The National Social Security Fund Council, unit: one hundred million yuan(RMB)

\begin{tabular}{|c|c|c|c|}
\hline YEAR & Amount & Yield $(\%)$ & Inflation rate (\%) \\
\hline 2001 & 7.42 & 1.73 & 0.70 \\
\hline 2002 & 19.76 & 2.59 & -0.80 \\
\hline 2003 & 44.71 & 3.56 & 1.20 \\
\hline 2004 & 36.72 & 2.61 & 3.90 \\
\hline 2005 & 71.22 & 4.16 & 1.80 \\
\hline 2006 & 619.79 & 29.01 & 1.50 \\
\hline 2007 & $1,453.50$ & 43.19 & 4.80 \\
\hline 2008 & -393.72 & -6.79 & 5.90 \\
\hline 2009 & 850.43 & 16.12 & -0.70 \\
\hline 2010 & 321.22 & 4.23 & 3.30 \\
\hline 2011 & 73.37 & 0.84 & 5.40 \\
\hline $\begin{array}{c}\text { Accumulated } \\
\text { investment income }\end{array}$ & 2845.93 & 8.40 & 2.40 \\
\hline
\end{tabular}

Such a significant loss occurs because, in addition to the overall market fell that year on outside (when the Shanghai index is down $65.16 \%$ ), also with the manager's investment mistakes and the absence of regulation of National Social Security Fund Council. The reasons for such massive loss are the overall market fell (the Shanghai composite index has fallen to $65.16 \%$ ), also with the manager's investment mistakes and the absence of regulation of the National Social Security Fund Council.

\section{The Reasons about Low Profit in the Capital Market for Social Security Fund}

\section{A. The fund company's technical operation errors}

Through researching the fund managers' ability in the stock investment can be obtained that the fund managers were wrong in entering time and the inadequate risk-awareness. (1) The entering time is wrong: in October 2007, the market changed from positive to negative, the Shanghai Composite Index and the stock price was way down, but this time the social security fund continues opening, until the market index fell more than $60 \%$ from the previous high. The social security fund has large losses. Thus, the social security fund investment managers not only failed to correctly predict in advance, but also were still slow after the trend has been established. They could not undertake corresponding adjustment, resulting in high to low in the market and serious 
losses. (2) The neglect of security. In accordance with the 'comprehensive-designable-initiative' investment principles, fund managers should take safety as the first principle and pursue the profitability on the basis of the capital safety. For example, in the end of September 2007, the market average p/e ratio was as high as 60 times, and the return on investment was less than $1.7 \%$. The capital market had been in a state of high risk and low income, but the fund managers still increase the stock holdings. Such an act of excessive speculation, also caused the social security fund's losses in stock investment in 2008.

\section{B. The development of the fund company is not mature enough}

China's fund industry was established a short time, but its development is fast. There are still many problems not been solved, such as legal blank, Imperfect capital market, insufficient human resources and operational experience, professional ethics and other issues; In particular, that the development of the fund company is not maturity is mainly manifested in the following aspects: (1) The industry development is still in the initial growth stage, and is also very low compared with developed countries and regions, the overall market size is small, standardization level remains to be improved, the system structure is imperfect, the operation behavior is not yet mature, also do not have the fund company's perfect evaluation system, fund manager's performance is stably need further study through practice. (2) Domestic fund managers generally too young, in spite of the degree is high, and the statistics show that fund managers with an average age of only 35 years old and less than $20 \%$ are over the age of 40.The similar data is 44 years in the United States. More main, most managers' experience is obviously insufficient. In addition, the fund manager changes too frequently. In 2009, a total of 350 fund managers took office and 197 fund managers resigned. It has many bad effects on the fund performance.

\section{The for-profit nature of the fund companies in China}

The fund company's profitability is mainly manifested in the following aspects: first is by sharing the fund gains, the second is by fund management fee. The fund management fee used to support the fun companies in the process of operation, no matter the outcome of fund managers operating is, fund companies will be profitable. Such as: fund industry-wide sustained losses of 6.726 billion yuan in 2004, the fund company won $\$ 3.528$ billion income. The huge contrast shows that fund investors silently suffer huge losses, while the fund manager has enjoyed enormous benefits.

Although the fund company shareholders' long-term interests is consistent with the social security fund, but there are still some contradictions in the short-term profits. Fund company shareholders pay more attention to their short-term interests, and thus put great pressure on fund managers and make them take risks, and even to violate operation principles. Therefore the risk of investment losses is increased and the social security fund's long-term interests are damaged.

\section{The Feasibility Countermeasures to Prevent Loss of Social Security Fund in Capital Market}

In the face of many problems of social security fund in the capital market, we must carry on the multidimensional aspects of improvement, including the adjustment of the social security fund council's investment philosophy, and strengthening supervision of fund companies, prompting talent incentive system, and the internal governance structure and mode of charges and so on, to make the social security fund truly realize increasing its value on the basis of security. Specific improvement measures mainly include the following aspects:

A. To enable the fund companies to promote the talent incentive system and take a series of measures to retain talented people, in order to ensure a higher level of investment. To establish a fair and reasonable talent incentive mechanism, including a fair assessment system and a reasonable salary incentive system, at the same time within the company to form a reasonable "flow", including horizontal multi- job training and vertical position up-down mechanism, make people get a fair rewards and punishment and promote their healthy development.

$B$. To promote the internal governance structure of the fund companies. Securities investment fund in China are all contractual fund .Because its governance structure itself is flawed, it cannot protect the interests of the investors. The lack of order in the capital markets and the relaxed regulation magnified these defects and leaded to the social security fund large losses. The most direct difference between the company funds and the compact funds is that there is a mechanism to protect the rights and interests of fund investors in the company funds. Therefore, in the process of perfecting our country's investment fund governance structure, we can consider introducing company funds. When conditions are ripe, we can pilot the company investment fund in insurance companies and new type of fund companies.

$C$. Change the current security charge mode in fund companies. A revenue model makes the fund company don't care about the benefit level of its products. After all, as long as there is a stable size a steady stream of management fee income will be brought. So, to expand the scale has become the primary task of fund profits .Obviously, there are not substantial consistency between the income pattern of the fund companies and the value target of the social security fund. The key to change the contradiction between the fund companies and investors is to break the risk-free income pattern of fund companies. Let the economic interests of the fund company to a certain extent, pegged to the unit net value of the fund. These institutional investors will be motivated to invest.

$D$. The national social security fund council should limit the scale of investment in stock and appropriately adjust the investment philosophy. The social security fund's losses in the stock market have showed that safety is the first consideration of the social security fund. From the history of the social security fund in developed countries, most of the proceeds of the stock market is not high. China is one of the few in the 
world which entrust the social security fund to business institutions.

\section{References}

[1] Li Junxian, "the national social security fund investment in risk analysis and control ", northwestern university, $9 \sim 10,2008$

[2] The national social security fund council, the introduction of the national council for social security fund, http://www.ssf.gov.cn/, access time (on
February 10, 2010)

[3] China securities industry association, "the basic knowledge of securities market", Beijing: China financial economic publishing house, 2007.5

[4] Sun Guangde, Dong Keyong, "social security introduction", Beijing: China renmin university press, 2004

[5] China securities industry association, the securities investment fund, Beijing: China financial economic publishing house, 2009 